\title{
The effect of grass endophytes on earthworms and slugs under a turf mowing regime
}

\author{
Christopher G.L. Pennell ${ }^{1}$, M. Philip Rolston ${ }^{2,3}$, Chikako van Koten $^{4}$, Wade J. Mace ${ }^{5}$, \\ David E. Hume ${ }^{5}$ and Stuart D. Card ${ }^{5, *}$ \\ ${ }^{1}$ FPF Consulting Limited, 18 Bridget Lane, Rangiora 7400, Canterbury, New Zealand \\ ${ }^{2}$ The Foundation for Arable Research, PO Box 23133, Hornby, Christchurch 8441, New Zealand \\ ${ }^{3}$ Forage Science, AgResearch Limited, Lincoln Research Centre, Private Bag 4749, Christchurch \\ 8140, New Zealand \\ ${ }^{4}$ Knowledge and Analytics, AgResearch Limited, Lincoln Research Centre, Private Bag 4749, \\ Christchurch 8140, New Zealand \\ ${ }^{5}$ Forage Science, AgResearch Limited, Grasslands Research Centre, Private Bag 11008, \\ Palmerston North 4442, New Zealand \\ ${ }^{*}$ Corresponding author: stuart.card@agresearch.co.nz
}

\begin{abstract}
Earthworms are not a direct pest of turf grass but they are considered a problem on many sports fields, disrupting playability and aesthetics due to the castings they deposit on the playing surface. Also, a number of slug species are well-known foliage destroying pests of a number of agriculturally important crop species. Perennial ryegrass and tall fescue cultivars associated with selected Epichloë endophytes, originally developed for bird management at airports, were assessed to determine their deterrent properties towards worms and slugs. Plots sown with endophyte-free ryegrass had significantly higher numbers of worms and slugs than plots containing the same grass cultivar infected with the endophyte strain AR95. Also, plots sown with endophyte-free tall fescue had significantly higher numbers of slugs (but not worms) than plots containing the same grass cultivar infected with the endophyte strain AR601. Although more research is required on the exact mechanism of action, these results suggest selected novel endophyte-infected grass associations, such as those including the endophyte AR95, may substantially reduce populations of worms and slugs in areas where these grasses are sown.
\end{abstract}

Keywords Avanex, Epichloë, Festuca arundinacea, Gastropoda, Lolium perenne, Lumbricidae, Neotyphodium

\section{INTRODUCTION}

More than 16 species of earthworm (Lumbricidae), originally introduced from Europe, are regarded as important components of New Zealand agricultural soils benefitting soil structure and fertility (Prestidge et al. 1997; Drewry 2006). However, some of these species are regarded as a problem worldwide on sports fields by their excessive production of earthworm casts on playing surfaces. Earthworm casts are especially problematic on golf courses when their soil-rich casts become abundant enough to disrupt the maintenance, aesthetics, and playability of putting greens and fairways (Redmond et al. 2014). Casting occurs when earthworms ingest soil and leaf tissue to extract nutrients, then emerge from their burrows to deposit the faecal matter, or casts, as mounds of soil on the turf surface (Beckman 1999; Potter et al. 2011). Castings can adversely affect ball roll, and muddy and smother the grass when smeared or compacted by tyres or foot traffic. Many of 
the broadly toxic soil insecticides, including chlordane (an organochloride compound), have been banned over the last 30 years due to concern over damage to the environment and harm to human health (Singh et al. 2016). There are presently no chemical pesticides available for the control of earthworms on golf courses in North America, Europe, and most other countries where the game is played and no other synthetic compounds are currently being developed (Potter et al. 2010). Certain slug species can have significant unwanted impacts on agriculture and horticulture, as well as for the home gardener. Pest species eat foliage, fruits and vegetables faster than plants develop while also making crops aesthetically displeasing and more vulnerable to plant pathogens. Slugs are generally controlled through the use of molluscicide baits, which raises concerns around accidental poisoning of non-target animals (Grewal et al. 2001).

Tall fescue (Lolium arundinaceum (Schreb.) S.J.Darbyshire (=Festuca arundinacea Schreb)) is an important forage grass utilised throughout the moderate to high rainfall temperate zones of the world (Young et al. 2013) while perennial ryegrass (Lolium perenne L.) is the most common pasture species in New Zealand (Chapman et al. 2017). Many cultivars of these perennial coolseason grass species are purposely developed, and marketed, with the incorporation of selected strains of asexual fungi in the genus Epichloë. These fungi are beneficial endophytes that form mutualistic symbiotic associations with their grass hosts (Johnson et al. 2013; Leuchtmann et al. 2014). Artificial associations are developed mainly for the additional traits, particularly insect pest deterrence, that selected endophytes strains can confer to elite grass cultivars (Johnson et al. 2013; Thom et al. 2014).

AgResearch Limited, a Crown Research Institute (CRI) based in New Zealand, is a world leader in the research and development of artificial grass-endophyte associations. This CRI has a large collection of Epichloë strains for research and commercial development purposes (Johnson et al. 2013). Based on their secondary metabolite profiles, many of these endophyte strains were deemed unsuitable for pastoral use, specifically due to their high production of ergovaline, an alkaloid that is a powerful animal toxin (Schardl et al. 2012). Ergovaline, however, has been implicated in the inducement of an avoidance behaviour observed in a number of mammals and birds (Coley et al. 1995; Conover \& Messmer 1996; Panaccione et al. 2006). Coupled with their capability to produce lolines, which are potent insecticidal and insect deterrent compounds, these strains were deemed suitable from a wildlife deterrent perspective. Subsequently, two grass-endophyte products were developed in New Zealand. The first between a turf-type tall fescue cultivar, 'Jackal', intentionally infected with Epichloë coenophiala strain AR601was developed primarily as an avian deterrent at airports. The second was a turftype ryegrass cultivar, Colosseum, intentionally infected with Epichloë festucae var. lolii strain AR95 for use as a wildlife deterrent at sports fields and recreational areas (Pennell et al. 2016; Pennell et al. 2017a; Pennell et al. 2017b; Pennell et al. 2017c).

Preliminary observations (unpublished data) indicated that earthworm numbers were reduced in soil beneath turf sown with certain grass/endophyte associations. The aim of this project was to evaluate the potential impacts that deterrent grasses could have on earthworms and slugs (Gastropoda) under a turf-management regime.

\section{MATERIALS AND METHODS Earthworm trial}

A trial was conducted at the AgResearch farm, in Lincoln, New Zealand on a Wakanui silt loam soil containing 24 established plots (measuring $3 \mathrm{~m} \times 2 \mathrm{~m}$ ) of six selected grass lines, each replicated four times as described previously (Pennell et al. 2017c). Three of the grass lines comprised of perennial ryegrass cv. 'Colosseum': one that was endophyte-free (E-); one infected with an endophyte strain toxic to grazing livestock, also known as the common-toxic (CT) endophyte strain (Johnson et al. 2013); and one 
infected with endophyte strain AR95. The three remaining grass lines comprised of tall fescue: $\mathrm{cv}$. 'Jackal' that was endophyte-free (E-); cv. 'Jackal' infected with endophyte strain AR601; and grass line GT282 also infected with endophyte strain AR601 (Table 1). There was no original endophyte strain (or common-toxic equivalent) available to act as a control in cv. 'Jackal' so grass line GT282 was included instead. This is a turf-type cultivar that is slower growing than 'Jackal' and, therefore, will potentially require less maintenance if developed as a bird-deterrent grass. Plots were arranged in a randomised block design separated by a $0.5 \mathrm{~m}$ border of bare soil. Nitrogen $(30 \mathrm{~kg} /$ ha) in the form of urea was applied in autumn and spring each year from September 2015. Plots were mown to a level of $5 \mathrm{~cm}$ once the sward had reached approximately $10 \mathrm{~cm}$ using a mulching mower (John Deere International $\mathrm{GmbH}$, Switzerland) with clippings returned to the plots. The frequency of mowing was around twelve times a year. In the summer months, water was applied by means of an irrigation system via the use of sprinklers as necessary to maintain a healthy turf-type sward.
In September 2016, nearly two years after establishment of the plots, two soil samples $(20 \mathrm{~cm}$ wide to a depth of $15 \mathrm{~cm}$ ) were obtained from each plot using a spade. Each sample was broken up by hand and total earthworm numbers counted per sample. Individual earthworms were washed in tap water to remove soil sediment and subsequently placed in separate plastic containers per plot. These containers were filled with tap water and left for 8 hours in order to remove earthworm gut contents. The tap water was then replaced to keep the worms viable and active. Twenty-four hours later, each worm was dried on filter paper, identified to species level by morphological characterisation and weighed. The sampling was repeated in September 2017 on the same trial site.

\section{Slug trial}

The slug trial was conducted on the same established plots as for the worm trial. In September 2016, two wooden boards $(20 \mathrm{~cm} \times$ $20 \mathrm{~cm}$, with $2 \mathrm{~cm}$ thickness) were placed in opposing corners of each rectangular grass plot and left for 16 days. At this time, the boards were

Table 1 Mean earthworm numbers and weights, pooled from years 2016 and 2017, per plot, sown with selected grass-endophyte associations. P-values correspond to comparisons to endophyte-free control treatments of the same grass species.

\begin{tabular}{llllr}
\hline Treatment & $\begin{array}{l}\text { Mean worm } \\
\text { numbers } \pm \text { SE }\end{array}$ & P-value & $\begin{array}{l}\text { Mean worm } \\
\text { weight }(\mathrm{g}) \pm \mathrm{SE}\end{array}$ & P-value \\
\hline $\begin{array}{l}\text { Perennial ryegrass } \\
\text { Colosseum E- }\end{array}$ & $24 \pm 1.5$ & $\mathrm{n} / \mathrm{a}$ & $11.0 \pm 1.0$ & $\mathrm{n} / \mathrm{a}$ \\
Colosseum CT & $16 \pm 1.7$ & 0.017 & $7.2 \pm 1.0$ & 0.003 \\
Colosseum AR95 & $14 \pm 1.5$ & 0.001 & $5.9 \pm 0.8$ & $<0.001$ \\
Tall fescue & $18 \pm 1.9$ & $\mathrm{n} / \mathrm{a}$ & $8.1 \pm 0.7$ & $\mathrm{n} / \mathrm{a}$ \\
Jackal E- & $14 \pm 1.8$ & 0.315 & $7.0 \pm 1.0$ & 0.304 \\
Jackal AR601 & $15 \pm 1.7$ & 0.266 & $6.9 \pm 0.8$ & 0.274 \\
GT282 AR601 & & & & \\
\hline
\end{tabular}

E-=endophyte-free; CT=common toxic endophyte strain; AR95 and AR601 are wildlife deterrent endophyte strains 
turned over and the numbers of slugs present under the boards and on the plots covered with the boards were counted per plot. The same wooden boards were then cleared of slugs and placed in opposite corners of the same plots but not in the same corners utilised for the first assessment. After a further 16 days, boards were again turned over and the number of slugs counted per plot. The sampling was repeated in September 2017.

\section{Statistical analysis}

For the earthworm and slug data, linear mixed model (LMM) analyses were performed with statistical software SAS version 9.3. The LMM consisted of Treatment factor and Year $\times$ Replicate for blocking as fixed effects. The Year $\times$ Treatment effect was not significant, and hence, not included in the results. The LMM also modelled withinplot correlation among repeated measurements taken in 2016 and 2017 as random effects, using an unstructured covariance matrix.

\section{RESULTS}

\section{Earthworm trial}

The main worm species identified in both 2016 and 2017 were Allolobophora caliginosa, Lumbricus rubellus, and L. terrestris. There were no significant differences in the number of these species found on each type of plot. The highest
$(\mathrm{P} \leq 0.05)$ earthworm numbers were found in plots of the endophyte-free line of perennial ryegrass cv. 'Colosseum', with a pooled (from 2016 and 2017) mean number of 24 earthworms (Table 1). This grass line also recorded the highest pooled mean worm weight of $11.0 \mathrm{~g}$ (Table 1). Both the endophyte-infected lines of 'Colosseum' recorded significantly $(\mathrm{P} \leq 0.05)$ fewer worms and significantly $(\mathrm{P} \leq 0.05)$ less weight of worms than the endophyte-free 'Colosseum' line (Table 1). No significant differences were found between the number of worms counted on 'Colosseum' CT and AR95 plots or in the mean weight of these worms when comparing these grass lines (Table 2).

The endophyte-free line of tall fescue, cv. 'Jackal' recorded fewer $(\mathrm{P}=0.01)$ earthworms and a lower mean weight $(\mathrm{P}=0.02)$ compared with the endophyte-free line of perennial ryegrass, cv. 'Colosseum' (Table 1). Neither of the endophyte-infected tall fescue lines (GT282 and 'Jackal' infected with AR601) differed from the endophyte-free line of tall fescue ('Jackal') for numbers or weigh of earthworms (Table 1).

\section{Slug trial}

The plots sown with the endophyte-free line of perennial ryegrass cv. 'Colosseum' recorded a higher $(\mathrm{P} \leq 0.05)$ number of slugs, a mean of 38, than for any other treatment (Table 2). This

Table 2 Mean slug numbers, pooled from years 2016 and 2017, per plot, sown with selected grassendophyte associations. P-values correspond to comparisons to endophyte-free control treatments of the same grass species.

\begin{tabular}{llr}
\hline Treatment & Mean slug numbers \pm SE & P-value \\
\hline Perennial ryegrass & & \\
Colosseum E- & $38 \pm 4.2$ & $\mathrm{n} / \mathrm{a}$ \\
Colosseum CT & $26 \pm 4.6$ & 0.006 \\
Colosseum AR95 & $19 \pm 2.8$ & $<0.001$ \\
Tall fescue & & \\
Jackal E- & $26 \pm 2.4$ & $\mathrm{n} / \mathrm{a}$ \\
Jackal AR601 & $14 \pm 0.9$ & 0.001 \\
GT282 AR601 & $11 \pm 1.7$ & $<0.001$ \\
\hline
\end{tabular}

E-=endophyte-free; CT=common toxic endophyte strain; AR95 and AR601 are wildlife deterrent endophyte strains 
was significantly higher $(\mathrm{P}=0.0002)$ than the number of slugs found on the plots sown with the endophyte-free line of tall fescue cv. 'Jackal' that recorded a mean of 26 slugs (Table 2).

The endophyte infected lines of both $\mathrm{cv}$. 'Colosseum' and cv. 'Jackal' recorded fewer $(\mathrm{P} \leq 0.05)$ slugs across both years compared with their endophyte-free grass equivalents (i.e. those lines of the same grass species that lacked endophyte) (Table 2). Plots sown with cv. 'Colosseum' infected with endophyte strain AR95 recorded $>50 \%$ fewer slugs on them compared to the endophyte-free line of cv. 'Colosseum' while plots sown with Colosseum infected with the common toxic endophyte strain recorded $>30 \%$ fewer slugs compared to the endophyte-free line (Table 2). More than 45\% fewer were found in plots sown with tall fescue, cv. 'Jackal' that was infected with endophyte strain AR601 compared with the endophyte-free line of cv. 'Jackal' (Table 2). The main slug species identified in both 2016 and 2017 were Deroceras panormitanum and D. reticulatum. There were no significant differences in the number of these species found on each type of plot.

\section{DISCUSSION}

The turf-type ryegrass (L. perenne) cultivar, 'Colosseum', intentionally infected with strain AR95 of Epichloë festucae var. lolii and the turftype tall fescue (F. arundinacea) cultivar 'Jackal' intentionally infected with E. coenophiala strain AR601 were developed in New Zealand as wildlife deterrents and possess proven bioactivity against a wide range of animals including birds, insects, mice and rabbits (Finch et al. 2016; Pennell et al. 2016; Pennell et al. 2017a; Pennell et al. 2017b; Pennell et al. 2017c). The alkaloidal secondary metabolites peramine and lolines are believed to be largely responsible for the observed insect resistance in these grass-endophyte associations (Pennell et al. 2016) while another alkaloid, ergovaline, and clavines (biosynthetic pathway precursors to ergovaline), are believed to result in a reduced appetite, and potentially other physiologically effects, in small mammals and birds (Pennell et al. 2017b; Pennell et al. 2017c).

Control of earthworms is seen by many as controversial due to the unique and important role these species play in soil conditioning. However, as with any other species, populations that are out of place or too high may warrant control actions (Delahaut \& Koval 2002). Prestidge et al. (1997) stated that it is highly likely that earthworms, particularly shallow burrowing species that feed on dead plant material, would regularly ingest and/or come into contact with secondary metabolites produced by Epichloë infected grasses. For example, lolitrem B persists for at least 28 days in dead ryegrass (Prestidge \& Sprosen 1995). However, no consistent relationships between earthworm abundance and the presence of endophyte in ryegrass were observed (Prestidge et al. 1997). Differences experienced by the Prestidge et al. (1997) study and the current study could simply be explained by the secondary metabolite profile of the endophyte strains investigated and/or by the different management regimes applied to the sward. In a study conducted with tall fescue, earthworms (Eisenia fetida) fed solely on endophyte-infected leaf tissue actually showed a 3.6-fold increase in their mean growth rates than individuals fed endophyte-free leaf tissue (Humphries et al. 2001). In the present study, no difference in abundance or weight was observed between earthworms under endophyte-free or endophyte-infected tall fescue. Additionally, the results of the current study are comparable to those by Humphries et al. (2001) where these grass-endophyte associations had no impact on earthworm survival.

As with invasive rabbits, certain slug species can have significant unwanted impacts on agriculture and horticulture, as well as for the home gardener. Pest species eat foliage, fruits and vegetables faster than plants develop while also making crops aesthetically displeasing and more vulnerable to plant pathogens. Therefore, the level of deterrence observed from this study towards this group of terrestrial gastropod molluscs is encouraging. Previous research has implicated multiple endophyte-produced alkaloids in the 
deterrence of Deroceras spp. slugs. These invasive European species are recognised as pests in many agricultural systems (Barker 2008) and were the main slugs identified from this study. However, the interaction between these herbivores and endophyte-grass associations was shown to be complex. For instance, peramine had no effect on slugs while ergovaline and another alkaloid, ergotamine, actually appeared to be phagostimulatory (Barker 2008). Lolitrem B and lolines were implicated in reduced feeding of these particular slug species but the effect of these alkaloids was altered in the presence of other secondary metabolites (Barker 2008). In a related grass-endophyte system, Dactylis glomerata infected with Epichloë typhina, certain species of slug are actually reported as important vectors of endophyte spermatia leading to the cross fertilisation of stromata of different mating types of this fungus (Hoffman \& Rao 2014). Perennial ryegrass cultivar, 'Colosseum' infected with AR95 is known to produce the alkaloids ergovaline, lolitrem $B$ and peramine while tall fescue cultivar 'Jackal' infected with AR601 produces ergovaline and loline alkaloids (Johnson et al. 2013; Pennell et al. 2017c).

Humans have used various strategies for managing wildlife for thousands of years (Treves et al. 2006). Although more research is required on the exact mechanism of action, the results presented here suggest novel associations in grass infected with endophytes have considerable potential to reduce multiple pest species. This study has shown that tall fescue and ryegrass cultivars infected with selected strains of Epichloë endophyte, AR601 and AR95, respectively, can reduce the abundance of certain slug species while ryegrass infected with AR95 can also reduce the abundance of earthworms in turf. This type of wildlife management towards slugs and worms is eco-friendly and socially more acceptable than the use of other forms of control as the endophyte-grass association deters many animals but results in no lethal effects. Therefore, fescue and ryegrass cultivars infected with selected strains of Epichloë endophyte could be used to reduce earthworm numbers in playing fields and golf courses, and as a border around certain high value crops to protect them from slugs.

\section{ACKNOWLEDGEMENTS}

S. Monk of Grasslanz Technology Limited managed the nucleus and breeders seed multiplications. A.J. Hilditch of AgResearch Limited and B. Dibley of PGG Wrightson Seeds Limited provided technical assistance while P.M. Fraser and A. Horrocks of The New Zealand Institute of Plant \& Food Research Limited provided worm and slug identification. Funding was provided by Christchurch International Airport Limited (CIAL), the Foundation for Arable Research (FAR), Grasslanz Technology Limited and PGG Wrightson Seeds Limited. Avanex $^{\infty}$ is a registered trademark of PGG Wrightson Seeds Limited.

\section{REFERENCES}

Barker G 2008. Mollusc herbivory influenced by endophytic clavicipitaceous fungal infections in grasses. Annals of Applied Biology 153: 381-393.

Beckman P 1999. Earthworm casting creates maintenance nightmare. Penton Media http:// groundsmag.com/golf_courses/grounds_ maintenance_earthworm_casting_creates/. Accessed 8th May 2018.

Chapman DF, Bryant JR, Olayemi ME, Edwards GR, Thorrold BS, McMillan WH, Kerr GA, Judson G, Cookson T, Moorhead A, Norriss M 2017. An economically based evaluation index for perennial and short-term ryegrasses in New Zealand dairy farm systems. Grass and Forage Science 72: 1-21.

Coley AB, Fribourg HA, Pelton MR, Gwinn KD 1995. Effects of tall fescue endophyte infestation on relative abundance of small mammals. Journal of Environmental Quality 24: 472-475.

Conover MR, Messmer TA 1996. Feeding preferences and changes in mass of Canada geese grazing endophyte-infected tall fescue. Condor 98: 859-862. 
Delahaut K, Koval CF 2002. Earthworms: Beneficials or Pests? Grounds Maintenance: For golf and green industry professionals University of Wisconsin-Madison, Penton Media Inc. http://grounds-mag.com/mag/ grounds_maintenance_earthworms_ beneficials_pests. Accessed 8th May 2018.

Drewry JJ 2006. Natural recovery of soil physical properties from treading damage of pastoral soils in New Zealand and Australia: A review. Agriculture, Ecosystems \& Environment 114: 159-169.

Finch SC, Pennell CGL, Kerby JWF, Cave VM 2016. Mice find endophyte-infected seed of tall fescue unpalatable - implications for the aviation industry. Grass and Forage Science 71 659-666.

Grewal PS, Grewal SK, Taylor RAJ, Hammond RB 2001. Application of molluscicidal nematodes to slug shelters: A novel approach to economic biological control of slugs. Biological Control 22: 72-80.

Hoffman GD, Rao S 2014. Fertilization of Epichloë typhina stromata by mycophagous slugs. Mycologia 106: 1-7.

Humphries SS, Gwinn KD, Stewart AJ 2001. Effects of endophyte status of tall fescue tissues on the earthworm (Eisenia fetida). Environmental Toxicology and Chemistry 20: 1346-1350.

Johnson L, de Bonth A, Briggs L, Caradus J, Finch S, Fleetwood D, Fletcher L, Hume D, Johnson R, Popay A, Tapper B, Simpson W, Voisey C, Card S 2013. The exploitation of epichloae endophytes for agricultural benefit. Fungal Diversity 60: 171-188.

Leuchtmann A, Bacon CW, Schardl CL, White JF, Tadych M 2014. Nomenclatural realignment of Neotyphodium species with genus Epichloë. Mycologia 106: 202-215.

Panaccione D, Cipoletti J, Sedlock A, Blemmings K, Shardl C, Machodo C, Seidel G 2006. Effects of ergot alkaloids on food preference and satiety in rabbits, as assessed with geneknockout endophytes in perennial ryegrass (Lolium perenne). Journal of Agricultural and Food Chemistry 54: 4582-4587.
Pennell CGL, Popay AJ, Rolston MP, Townsend RJ, Lloyd-West CM, Card SD 2016. Avanex Unique Endophyte Technology - a biological deterrent for the aviation industries. Environmental Entomology 45: 101-108.

Pennell C, Rolston M, Koten C, Hume D, Card $S$ 2017a. Reducing bird numbers at New Zealand airports using a unique endophyte product. New Zealand Plant Protection 70: 224-234.

Pennell C, Rolston M, Baird D, Hume D, Mckenzie C, Card S 2017b. Using novel-grass endophyte associations as an avian deterrent. New Zealand Plant Protection 70: 255-264.

Pennell C, Rolston M, Latham A, Mace W, Vlaming J, van Koten C, Latham M, Brown S, Card S 2017c. Novel grass-endophyte associations reduce the feeding behaviour of invasive European rabbits (Oryctolagus cuniculus). Wildlife Research 43: 681-690.

Potter DA, Redmond CT, Meepagala KM, Williams DW 2010. Managing earthworm casts (Oligochaeta: Lumbricidae) in turfgrass using a natural by-product of tea oil (Camellia sp.) manufacture. Pest Management Science 66: 439-446.

Potter DA, Redmond CT, Williams DW 2011. Course Care: Controlling Earthworm Casts. http://www.usga.org/news/2011/October/ Course-Care--Controlling-EarthwormCasts/. Accessed 8th May 2018.

Prestidge RA, Sprosen JM 1995. The effect of glyphosate, paraquat and paclobutrazol on lolitrem B levels in endophyte-infected perennial ryegrass. New Zealand Veterinary Journal 43: 138-140.

Prestidge RA, Marshall SL, Thom ER 1997. Seasonal earthworm densities on endophyteinfected and endophyte-free perennial ryegrass. Proceedings of the New Zealand Plant Protection Conference 50: 73-77.

Redmond CT, Kesheimer A, Potter DA 2014. Earthworm community composition, seasonal population structure, and casting activity on Kentucky golf courses. Applied Soil Ecology 75: 116-123. 
Schardl CL, Young CA, Faulkner JR, Florea S, Pan

J 2012. Chemotypic diversity of epichloae, fungal symbionts of grasses. Fungal Ecology 5: 331-344.

Singh K, Hegeman WJM, Laane RWPM, Chan HM 2016. Review and evaluation of a chiral enrichment model for chlordane enantiomers in the environment. Environmental Reviews 24: 363-376.

Thom E, Popay A, Waugh C, Minneé E 2014. Impact of novel endophytes in perennial ryegrass on herbage production and insect pests from pastures under dairy cow grazing in northern New Zealand Grass \& Forage Science 69: 191-204.

Treves A, Wallace RB, Naughton-Treves L, Morales A 2006. Co-managing humanwildlife conflicts: a review. Human Dimensions of Wildlife 11: 383-396.

Young CA, Hume DE, McCulley RL 2013. Forages and pastures symposium: Fungal endophytes of tall fescue and perennial ryegrass: Pasture friend or foe? Journal of Animal Science 91: 2379-2394. 